\title{
The Multimedia Application in Middle School English Teaching
}

\author{
Yang Zhao
}

Foreign Languages College, Beihua University, Jilin 132013, China.

\author{
KeyWords: multimedia application English teaching traditional English
}

\begin{abstract}
As we know, the traditional teaching activity stuck to the teacher's teaching. It paid much attention to the results of the development of the students' comprehensive ability. The language environment in traditional teaching model restricted students' English learning. That caused to form "silent English". This paper puts forward to the superiority of multimedia technology in English teaching, offers some suggestions to optimize multimedia technology properly, which consider multimedia technology as ancillary equipment; to follow the principle of "timely, moderate, appropriate"; teachers should grasp modern technology actively. Facing the development of information technology, we should deal with it actively, change the ideas and roles, and make full use of it to serve for the teaching activity to improve the teaching quality.
\end{abstract}

\section{Introduction}

With the development of computer technology, various usage of multimedia assisting English teaching promotes the development of teaching aim, teaching methods and teaching artifice. The traditional "one chalk and one blackboard" teaching style can not meet the necessity of higher qualified English language-learners. Therefore, the command of English language teaching in middle school is to train students in listening, speaking, reading, writing and translating. Facing this challenge, the traditional teaching style can not hold out, while multimedia technology which is of direct observation, vividness, convenience, swiftness and practicability, synthesizing audio, video, animation and words, can extremely enrich the teaching methods, enlarge the teaching tensity and improve the students' productiveness. Meanwhile, with the help of multimedia technology, teachers can create and stimulate a vivid environment to bring the real life to class, to shorten the distance between teaching and reality, to train them to think in English and to give them the opportunity to communicate in English.

\section{Certain shortcomings existed in traditional English}

As we know, there are certain shortcomings existed in traditional English educational model. The shortcoming mainly reveals in the aspect sticking to teachers' teaching but ignores the students' learning. It does not help the students gain knowledge by themselves, but put them in class to listen and follow what the teachers have told them passively, then make them stay at home to do a large amount of homework. All these destroy the students' desire to study. There are mainly two reasons causing this problem. Firstly, our traditional thought in education has blocked the development of English teaching. We pay much attention to the results of examinations. We don't consider English as a language tool that the students should master. Teachers who take English as their major only command their students to get higher marks in exams, not to raise their interest or their ability of thinking. That makes to form "silent English"; secondly, the language environment restricts the students' English learning. In our country, English learning mainly depends on English classes. Students can only share the language environment for 40 minutes, while during other time, there is little language environment. Therefore, it is difficult for students to master a language only depending on classes.

\section{The superiority of multimedia technology in English teaching}

Since media appears, people generally consider media as the intermediary or tool to bear, 
disseminate and transfer the information. When the media used for teaching aim, it is called teaching media. The rise of multimedia technology breaks the tie of traditional media. It makes the optimum composition to be reality. The multimedia can show the picture, words, animation, etc. It can stimulate the real world, therefore, it can reappear the real language environment. The students can study actively and freely in the environment. Facing different scenes, they can talk with the characters in the plays or answer questions asked by the characters. They can also gain teaching messages by thinking and analyzing according to the prompt of teaching software, and finish kinds of questions. Applying the multimedia technology to English teaching can develop the students' language skills comprehensively and play a very important role to advance their language application.

Interest is the tendency that people do research on something. Gardner has ever said that the intention to learn the second language contains four aspects as bellow: the aim of learning the second language, the efforts made during study, the desire for achieving the aim and the interest to learning. That shows that interest is the best teacher for learning. If people are interested in something, they will understand it and master it at all costs. As we know, multimedia teaching aids can appear the teaching contents by using words, pictures (still or active) and audio. And that consists with the psychological characteristics of the students and enlivens the atmosphere of classroom. In this environment, the teaching contents are more obvious, the teaching process is more scientific, the teaching method is more reasonable, the students' interest is clearer. We can explain this phenomenon by drawing support from medical knowledge. Brain waves can be divided into three kinds. When the frequency is between $14-26 \mathrm{~Hz}$, it is called B wave. People would be in tension, if it is B wave. This tension is caused by people's dealing with problems wholeheartedly or people's excitement or hurry or tension. If we can make full use of this special physiological phenomenon to show the English knowledge to the students with the help of scientific, vivid, visual multimedia technology that would directly stimulate this kind of brain wave, so that the receiver would accept the English knowledge actively in a delightful, relaxed, innovative formed situation. It is both time-saving and highly effective.

It is a good way to transfer from the traditional teacher-centered teaching model to student-centered model by teaching multimedia technology. It is both-direction teaching style. The teacher can raise the students' language ability by creating kinds of language environment, while the students can check their learning result by doing the questions created by multimedia. At the same time, the students' learning results can be feedback to the teacher by reading. Five basic language skills are listening, speaking, reading, writing and translating. Multimedia class can make full use of improving these five skills. Meanwhile, many kinds of games and competitions can be held to give the students opportunity of practicing. That does not only train their teamwork, but also enhance their sense of group honor. It is a good way to help students form an optimistic, self-confident and active character to improve their comprehensive capacity.

When putting the theory into practice, we conclude the usage as followed before class: playing some exquisite music to keep students silent and relax them to induct the new class. In class, it can optimize the blackboard writing and enrich the teaching contents. We can train the students' reading ability by playing some standard pronunciation.

The application of multimedia makes the students be busy with dealing the dazzling courseware screen. The teachers have to divert their attention to the courseware's successful joint. So to some extent, multimedia hinders the communication between teachers and students, and also kills the vividness of class. The teaching process is a very complex and exquisite process, and also is the process of students' cognition and building knowledge. Even it is the process of communication between teachers and students. Students are the center in the learning process, while the computer is an object which has no emotion, so it can not communicate with students. But in the process of traditional teaching, teachers play a decisive role, they occupy the leading position, they are the leading part in teaching process, which propagate the teaching contents, design the teaching tactics, and evaluate effect of students' study. With the development of informational technology, traditional teaching pattern is assaulted heavily and teachers' role varies in teaching gradually. In the past, the 
class is controlled by the teachers, now many teachers are controlled by the computers. After multimedia appears, the teachers' leading role changes into good record sound. After having multimedia, the writing on blackboard relatively reduces.

Some teachers take multimedia as projector of tape recorder. As a result, the class is dull and monotonous. There are some unsatisfied points in multimedia application assisting teaching process. For instance, pay attention to performance, but ignore the revealed process; on image thinking, ignore abstract thinking; on the teachers' teaching process, ignore the students' learning process. These all spread bad effects on the achievement of teaching aim that is the development of innovation and creating ability.

"Timely" is to choose the teaching points which are good for the students and the time which makes teaching process achieve the best effect. For instance, if the important points have not attracted the students' attention, or if the students can not imagine, or if the students meet some difficulties, or if the teacher needs to check the teaching result, we can turn to the multimedia help. "Moderate" is that multimedia should use the "wonderful" place to arouse students' interest in learning, use the place where the students can understand the teaching contents. "Appropriate" is that using multimedia should not be abused and also should not be deserted. In the process of English teaching, using the multimedia technology should grasp the principle of "timely, moderate, appropriate" to find the enter point of multimedia and teaching contents. At the same time, enhance the target of multimedia application assisting English teaching process, and avoid teachers depending more on multimedia way. English teachers should know that multimedia is just the way to help teaching, and get the best teaching effect. Only the teachers can design according to the teaching points and difficulties, grasp the depth of teaching contents, use the multimedia technology reasonable, and then can get the best teaching effect.

In order to add some entertaining aspects, the designers often add some music or a part of film editing. Even though this decoration can satisfy the students' interest, it has nothing to do with teaching contents sometimes. Therefore, we should obey certain rules: to choose the materials according to the training goal. If the theme is Christmas Day, we should choose the additional materials related to Christmas, if we want to add some music, we'd better choose the Christmas music to make the whole teaching process connect proper to avoid the waste of teaching time.

\section{Summary}

Human being's activities do gradually promote the development of society, while the development of society and technology can greatly put forward educational development. In such kind of information society, we should adapt actively, make full use of developing information technology to train students' creating and practicing ability. This is the way to improve teaching quality. Practice has proved that multimedia application assisting English teaching is much better than traditional classroom teaching. It teaches in the student-centered style. It is better for developing the students' independent learning ability. To teach by using multimedia courseware or disk can shorten the teaching time and offer more opportunity to stimulate the students' learning activity. All in all, 21st century is a century that is full of opportunity and challenge. It is also a century in which English teaching can be improved and developed, multimedia application brings new activity for English teaching. At the same time, it is a new course for teachers to exploit and create many useful experiences to meet the need of multi-methods in English teaching revolution and improve the quality of English teaching, meanwhile, to build a teacher who is not only good at one skill but multi-skill.

\section{References}

[1] Chaptal, A., New and Traditional Educational Media: How to choose between them-Teachers' Choices, Educational Media International, 1998, VOL12.

[2] Cohen, A. D., Strategies in Learning and Using a Second Language, Foreign Language Teaching 
and Research Press, 2000.

[3] Kozma, R. B., A Reply: Media and Methods, Educational Technology Research \& Development (ETR\&P), 1994, VOL42.

[4] Xu Fuyin, Li Yunlin, theory and practice of teaching media, Beijing Normal University press, 2003 